\title{
Cloning and Expression of a Gene Encoding a Putative Chloroplast $\omega 6$ Fatty Acid Desaturase of Marine Chlamydomonas
}

\author{
Hitoshi MIYASAKA*, Satoshi TANAKA and Haruo KANABOSHI
}

\author{
The Kansai Electric Power Co., Technical Research Center, 11-20 Nakoji 3-Chome, Amagasaki, \\ Hyogo 661-0974, Japan \\ * Corresponding author E-mail address:
}

Received 16 October 1999; accepted 13 March 2000

\begin{abstract}
A cDNA encoding putative chloroplast $\omega 6$ fatty acid desaturase was isolated from a cDNA library of marine Chlamydomonas sp. strain $\mathrm{W}-80$. The mRNA level of this gene under various conditions of stress was examined by northern blotting analysis, and the transcript level was increased under a coldstressed $\left(4^{\circ} \mathrm{C}\right)$ condition.
\end{abstract}

Low temperature is one of the commonest and the most deleterious environmental stress for living organisms. Under low temperature, the desaturation of fatty acid in membrane lipids plays an important role in the maintenance of fluidity of membranes (Murata and Wada, 1995; Los and Murata, 1998). When the fluidity of membrane lipids is reduced by a low temperature, double bonds are introduced into the fatty acids of lipids, so that the membranes keep the fluid state. Omega $(\omega) 6$ fatty acid desaturase catalyzes the desaturation of monoenoic to dienoic fatty acid. In cyanobacteria (Los and Murata, 1998; Sakamoto and Bryant, 1997), the mRNA level of $\omega 6$ desaturase (delta 12 desaturase) is dramatically increased when the cells are exposed to a low temperature condition. On the other hand, in soybean (Heppard et al., 1996) and Arabidopsis thaliana (Okuley et al., 1994), no increase in $\omega 6$ desaturase transcript was observed under low temperature, even though the levels of polysaturated fatty acids in the plant were elevated, and the transcript level of $\omega 3$ desaturase was also increased. Regarding algae, there is no study on the regulation of expression of the $\omega 6$ desaturase gene under a low temperature condition.

In this study, the cDNA clone of chloroplast $\omega 6$ desaturase homologue was isolated from the cDNA library of marine Chlamydomonas sp. strain W-80, and the mRNA levels of this gene under various conditions of stress, including cold stress, were examined by northern analysis.

The marine Chlamydomonas sp. strain $\mathrm{W}-80$ used in this study was isolated in the coastal area of Wakayama, Japan, and was identified as a Chlamydomonas species as described previously
(Miyasaka et al., 1998). This algal strain is highly tolerant both to salt stress (up to $2 \mathrm{M} \mathrm{NaCl}$ ) and to oxidative stress (up to $100 \mu \mathrm{M}$ methyl viologen; MV). Modified Okamoto medium (MOM; pH 8.0) supplemented with $5 \mathrm{mM} \mathrm{NH}_{4} \mathrm{Cl}$ was used for algal cultures (Miura et al., 1986), and the algal cultures were continuously illuminated by fluorescent lamps at a light intensity of $175 \mu \mathrm{E} \mathrm{m}^{-2} \mathrm{~s}^{-1}$, with aeration by bubbling at a rate of $200 \mathrm{ml}$ air/min. The $\lambda$ ZAPII (Stratagene, La Jolla CA, USA) cDNA library of Chlamydomonas W-80 was constructed as described in a previous paper (Miyasaka et al., 2000). The Luria-Bertani (LB) medium supplemented with $50 \mathrm{mg} \mathrm{m}^{-1}$ of carbenicillin $(\mathrm{Cb})$ was used for Escherichia coli (SOLR strain, Stratagene) cultures. The bacterial cell growth was monitored by measuring the $\mathrm{OD}_{600}$ of cultures.

A cDNA clone of the $\omega 6$ desaturase homologue was isolated from the cDNA library by a functional expression screening method with $E$. coli cells as described previously (Miyasaka et al., 2000). Briefly, the $\lambda$ ZAPII cDNA library was mass excised into phagemid DNA, and the host $E$. coli cells carrying the mass excised phagemid DNA were plated onto the selection plate with a high concentration $(5 \%)$ of $\mathrm{NaCl}$. The plates were incubated at $37{ }^{\circ} \mathrm{C}$ for 2 days and the salt-stress tolerant bacterial colonies were isolated.

The acquisition of salt-stress tolerance of the $E$. coli cells carrying algal $\omega 6$ desaturase gene homologue was further confirmed by back-inoculating the phagemid DNA into the host $E$. coli cells, and by checking the acquisition of stress tolerance of the newly-generated transformants. Fig. 1 shows the growth curves of the $E$. coli cells with 

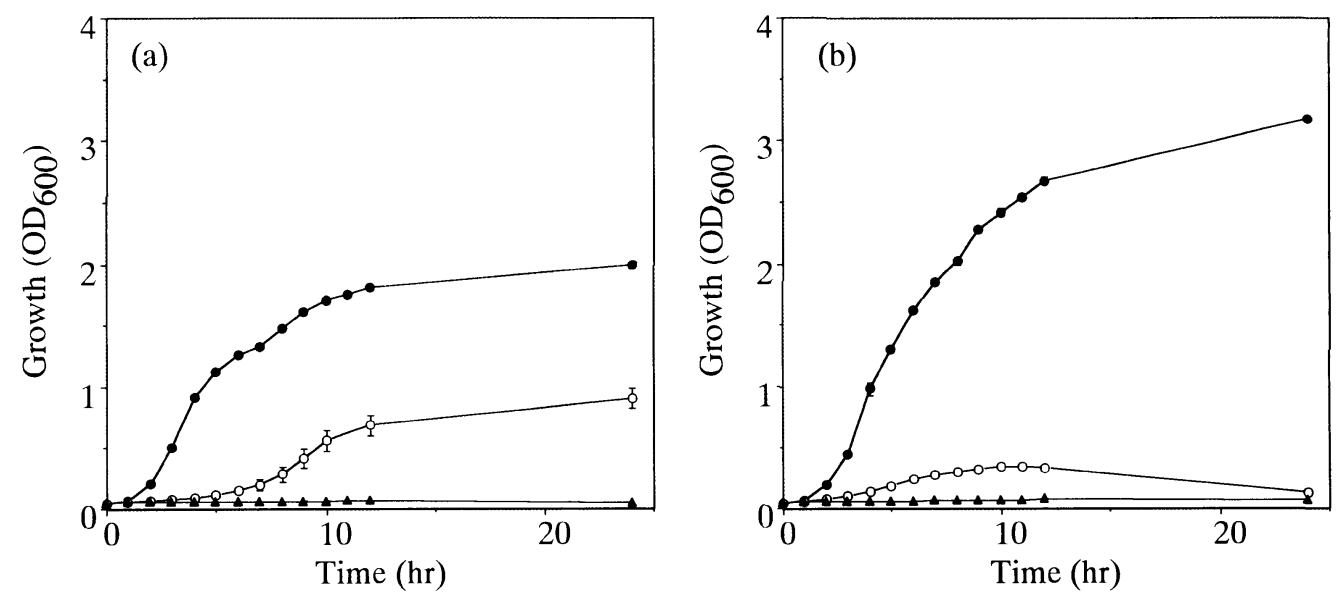

Fig. $1 \mathrm{NaCl}$ salt-stress tolerance of $E$. coli cells carrying algal $\omega 6$ desaturase homologous gene. The $E$. coli cells with algal $\omega 6$ desaturase homologous gene (a), and with pBluescript vector (b) were cultured in LB- $\mathrm{Cb}$ medium with $1(\bullet), 5(\circ)$, and 7\% ( $\Delta$ ) $\mathrm{NaCl}$. One percent is the standard $\mathrm{NaCl}$ concentration in $\mathrm{LB}$ medium. Cell growth was monitored by measuring the $\mathrm{OD}_{600}$ of cultures. Values are the means \pm standard error for three cultures.

Chlamydomonas W-80 $\omega 6$ desaturase homologue (a) and with pBluescript vector (b) in the $\mathrm{LB}-\mathrm{Cb}$ medium with 1,5 , and $7 \% \mathrm{NaCl}$. In the $1 \% \mathrm{NaCl}$ (standard concentration in LB medium) medium, the growth of the $E$. coli cells with $\omega 6$ desaturase homologue was considerably lower compared to that of the control, suggesting that the expression of this gene has some suppressive effects on the cell growth. In the $5 \% \mathrm{NaCl}$ medium, the control cells showed only a slight increase in $\mathrm{OD}_{600}$ value for 10 hours after the inoculation of the cells, but no growth was observed after 24 hours, while the cells with $\omega 6$ desaturase homologue kept growing and reached approximately $45 \%$ of the $1 \% \mathrm{NaCl}$ culture after 24 hours, indicating that the expression of the $\omega 6$ desaturase homologue has a protective function against the $\mathrm{NaCl}$ salt stress in $E$. coli cells. In the $7 \% \mathrm{NaCl}$ medium, no cell growth was observed in either the cells with $\omega 6$ desaturase homologue or with the pBluescript vector. The reason the $E$. coli cells with the algal $\omega 6$ desaturase gene acquired the tolerance against the salt-stress is, however, not clear, and further studies are required in the future to examine the physiological significance of the expression of algal $\omega 6$ desaturase homologue in $E$. coli cells.

The DNA sequence of cDNA clone of $\omega 6$ desaturase homologue of Chlamydomonas W-80 was determined completely from both strands. The cDNA clone (DDBJ accession No. AB031546, sequence data not shown) was 1,565 bp long, with 31 bp of poly(A) tail, and had a 1,263 bp coding region (421 amino acids, calculated molecular mass of 47,930), and $122 \mathrm{bp}$ and $149 \mathrm{bp} 5^{\prime}$ and $3^{\prime}$ noncoding regions, respectively. The coding region of this gene was located in the proper reading frame forming the fusion protein with the $\beta$-galactosidase gene of the pBluescript vector. The sequence TGTAA, a putative polyadenylation signal, was found $13 \mathrm{bp}$ upstream of the poly(A)-tail. The deduced amino acid sequence of $\omega 6$ desaturase homologue of Chlamydomonas W-80 showed $67 \%$ homology to that of fresh water green alga Chlamydomonas reinhardtii (Sato et al., 1997), 50 to $55 \%$ to higher plant $\omega 6$ desaturases (Hitz et al., 1994; Falcone et al., 1994), and 45 to $52 \%$ to cyanobacterial delta 12 desaturases (Schmidt et al., 1994; Sakamoto et al., 1994). Although the $\omega 6$ desaturase homologue of Chlamydomonas W-80 showed a relatively low homology to other known $\omega 6$ desaturase genes, it had three His-clusters which were reportedly essential for the desaturation reaction (Shanklin et al., 1994). The amino acid sequence, around these His-clusters, of the $\omega 6$ desaturase homologue of Chlamydomonas W-80 were also well conserved (Fig. 2); we therefore concluded that the isolated gene was the $\omega 6$ desaturase homologous gene of Chlamydomonas W-80. The $\omega 6$ desaturase homologue of Chlamydomonas W-80 had a potential chloroplast transit peptide (Franzen et al., 1990) in its $\mathrm{N}$-terminal region, and was expected to be a chloroplast enzyme.

To examine the regulation of $\omega 6$ desaturase homologous gene expression in Chlamydomonas W - 80 cells, the mRNA levels of this gene under various conditions of stress were examined by northern blotting analysis (Fig. 3). For the northern blotting experiment, approximately 1.5 liter of algal cultures in the early logarithmic phase $\left(\mathrm{OD}_{680}=0.8\right)$ in 2 liter flat culture bottles were exposed to various 


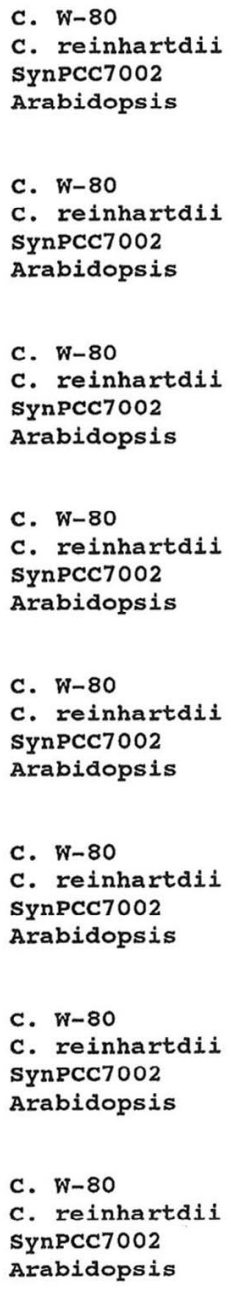

KVRTAAPAMTVSDPTKAGFMSDEDRAALAKELGYRQLGKELPDHVTLNTIVQSMPKEVFE VARPQVQTNAAALSV PVNQLTDEERANLARELGTKS I GRELPDNVSLTDI IKSMPAEVFK - - - MTSVTVRPSATTLLEKHP-_-_-_-_- NLRLRDILDTLPRSVYE KRRIGCIKAVAAPVAPPSADSAEDREQLAESYGFRQIGEDLPENVTLKDIMDTLPKEVFE * * * * *

IDHGKAWRAVLTSITAMAGCLYLISVS PWYLLPF AWALAGTAFTGFFVVGHDAGHRSFHK LDHGKAWRACLTTIAACSACWYLISIS PWYLL PAAWAIAATAFTGCFVIGHDCGHRSFHE INPLKAWSRVLLSVAAVVGCY ALLAIAPWYLLL PVWFLT GTTLTGFFVIGHDCGKRSFSR INPLKAWSRVLLSVAAVVGCY ALLAI APWYLLLPVWFLTTTLTGFFVIGHDCGHRSFSR

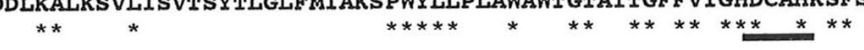

NNL IEDIVGT IMF API, IY PFEPWRTKHNHHHAHTNKIEEDTAWVP IEOEKMRDWNGVTSA NNL IEDIVGHIFF APLIY PFEPWRIKHNHHHAHTNKLVEDTAWHPVTEADMAKWDSTSAM KNWVNNLVGHLAFLPLIY PFHSWRILHNHHHRY TNNMDEDNAWAPFTPEL YDDSPAF IKA NKLVEDIVGTLAFLPLVY PYEPWRFKHDRHHAKTNMIVHDTAWQPVPPEEFESSPVMRKA ** ***** ***********

LFKFFLGTPLKLWASVGHWAIWHFDLNKYTEKQRPRVIVSLLACAAFACTVLPWLVINHG LYKVFLGTPLKLWASVGHWLVWHFDLNKYTPKORTRVVI SLAVVY GFMATAFPALLYFGG VYRAIRGKLWWLAS -VIHOLKLHFNWF AFEGKOREQVRF SALFVI I AGAI AF PVMF YTLG IIF GY GPIRPWLS--IAHWVNWHFNLKKFRASEVNRVKI SLACVF AFMAVGWRLIVYKVG * * ** * * *

VWGLVKYWL MPWLGYHFWMSTFTVIHHTAPHI PFKPAAEWNAAKAQLSGTVHCDFPAWVE PWAFVRYWL MPWL GYHFWMSTFTVVHHTAPHIPFKK AEEWNAAKAOLS GTVHCDFPNWVE PWAFVRYWLMPWLGYHFWMSTFTVWHTH ILGWVKFWLMPWL GYHFWMSTFTMVHHTAPHI PFKPADEWNAAQAQLNGTVHCDYPSWIE $* * * * * * * * * * * * * * * * * * \quad * * * * * * * \quad * * * * * * * * * * * * * * *$

FLTHDI SVHVPHHVSSKI PWY NLRKAHASLKENWGEHMCETTFNWRMLKNIFTELHVYDE FLTHDISWHVPHHVAPKI PWYNLRKATE SLRENWGQYMTECTFNWRVVKNICTECHVYDE VLCHDINVHVPHHLSTGIPSYNLRKAY ASIKQNWGEYLYETKFSWELMKAITEQCHLYDA ILCHDINVHI PHHI S PRI PSY NLRAAHESIQENWGKYTNLATWNWRLMKT IMTVCHVYDK $* * * * * * * * * * * * * * * * * * *$ * $* * * * *$

\section{KTFGYKPFDWKKEEPLFAAQRAAYPNSM--}

KVN-YKPFDYKKEEALFAVQRRVLPDSAAF



Fig. 2 Alignment of amino acid sequences of $\omega 6$ desaturase of Chlamydomonas W-80, Chlamydomonas reinhartdii, Synechococcus PCC7002 (SynPCC7002; delta 12 desaturase) and Arabidopsis thaliana. Asterisks indicate the amino acid conserved in all the sequences. The three His-clusters essential for the desaturation reaction are underlined. The alignment was computed with the CLUSTAL w program (Thompson et al., 1994).



$2.37 \mathrm{~kb} \rightarrow$

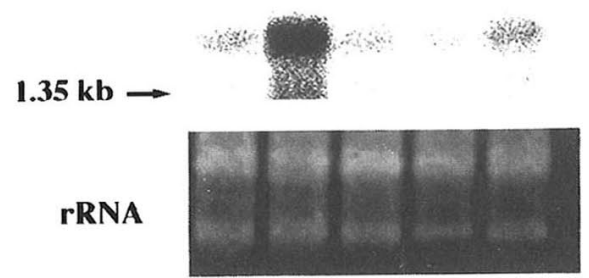

Fig. $3 \omega 6$ desaturase homologue mRNA accumulation in Chlamydomonas W-80 grown under various conditions of stress. Algal cells were exposed to various kinds of stress (heat, cold, oxidative, and high salt stresses) for 6 hours under a continuous illumination $\left(175 \mu \mathrm{E} \mathrm{m}^{-2} \mathrm{~s}^{-1}\right)$. Each lane contains $12 \mu \mathrm{g}$ of total RNA isolated from the stress-treated algal cells. rRNA shows the RNA sample stained with ethidium bromide. kinds of stress, such as heat, cold, oxidative, and high salt stresses, for 6 hours under continuous illumination $\left(175 \mu \mathrm{E} \mathrm{m}^{-2} \mathrm{~s}^{-1}\right)$. For salt stress, the $\mathrm{NaCl}$ concentration in the medium was elevated from $0.5 \mathrm{M}$ (standard concentration of MOM) to 1.5 $\mathrm{M}$ by adding solid $\mathrm{NaCl}$. For oxidative stress (200 $\mu \mathrm{M} \mathrm{MV}), 1.5 \mathrm{~m} l$ of the $0.2 \mathrm{M}$ stock MV solution was added to the culture medium; $\mathrm{MV}$ can be reduced by the photosynthetic apparatus yielding a monocation radical, which rapidly generates superoxide $\left(\mathrm{O}_{2}{ }^{-}\right)$(Rabinowitch et al., 1987). For heat and cold stresses, the cells were cultured at $38{ }^{\circ} \mathrm{C}$ and at $4{ }^{\circ} \mathrm{C}$, respectively. The effects of $\mathrm{NaCl}$ and $\mathrm{MV}$ on algal cell growth were examined in advance by culturing the cells in the liquid medium with various concentrations of these substances (data not shown), and the concentrations which caused approximately $30 \sim 50 \%$ growth inhibition have been chosen for the northern blotting experiment.

After the treatment with various conditions of stress for 6 hours, total RNA was extracted from the 
algal cells with the ISOGEN RNA extraction kit (Nippon Gene, Toyama, Japan). Twelve micro grams of total RNAs were electrophoresed on a $1.2 \%$ agarose $/ 2.1 \%$ formaldehyde gel, and transferred to a Nytran membrane (Schleicher \& Schuell, Keene $\mathrm{NH}$, USA) by capillary blotting with $10 \mathrm{x}$ SSC (1.5 $\mathrm{M}$ sodium chloride/0.15 $\mathrm{M}$ sodium citrate, $\mathrm{pH} 7$ ). The RNA was immobilized by UV crosslinking, and the northern blot was hybridized overnight at $42{ }^{\circ} \mathrm{C}$ in $50 \%$ formamide $(\mathrm{v} / \mathrm{v}) / 0.2 \%$ SDS (w/v)/2 $\mathrm{x}$ Denhardt $/ 6 \times \mathrm{SSC} /\left(100 \mathrm{mg} \mathrm{m} l^{-1}\right.$ calf thymus DNA) with a ${ }^{32} \mathrm{P}$-labeled probe. The ${ }^{32} \mathrm{P}$-labeled probe was prepared by random priming using the PCR-generated template of Chlamydomonas $\mathrm{W}-80 \omega 6$ desaturase homologue. After hybridization, the membrane was washed with $2 \times$ SSC/0.1\% SDS for 15 min at room temperature, $2 \times \mathrm{SSC} / 0.1 \%$ SDS for $15 \mathrm{~min}$ at $65{ }^{\circ} \mathrm{C}$, and $0.2 \times \mathrm{SSC} / 0.1 \%$ SDS for 20 min at $65^{\circ} \mathrm{C}$ twice. The membrane was exposed to a Fuji imaging plate (Fuji Film, Tokyo, Japan), and the hybridization signals were quantified with a BAS 2000 reader (Fuji Film).

The single mRNA was detected to be approximately $1.6 \mathrm{~kb}$, indicating that our $\omega 6$ desaturase homologous cDNA clone $(1,565 \mathrm{bp}$ with $31 \mathrm{bp}$ poly (A) tail) is full-length. The level of transcript of the $\omega 6$ desaturase homologue increased 2.3-fold in the cold-treated cells compared to non-stressed control cells, while the transcript levels under the other stressed-conditions were $62 \%(\mathrm{NaCl}$ salt stress), $80 \%$ (MV oxidative stress), and $87 \%$ (heat stress) of the control (no stressed condition), respectively. Thus the mRNA level was increased specifically under a cold-stressed condition in the algal cells, suggesting that in algal cells the expression regulation of $\omega 6$ desaturase plays an important role, the same as in cyanobacteria, in the membrane lipid desaturation process under a low temperature condition.

\section{Acknowledgments}

Chlamydomonas sp. W-80 strain was isolated by Prof. Y. Miura (Prof. Emeritus of Osaka University), and has been maintained by him, Prof. T. Mizoguchi (Prof. Emeritus of Osaka University), and Associate Prof. K. Yagi (Faculty of Pharmaceutical Sciences, Osaka University, Japan). We thank them for their kind permission to use this algal strain in our study.

We thank Dr. S. Kanai of Toray Research Center Inc. for his help with northern hybridization.

We also thank Dr. G. Clendennen for his editorial revision of this manuscript.

\section{References}

Falcone, D. L., Gibson, S., Lemieux, B., Somerville, C., 1994. Identification of a gene that complements an Arabidopsis mutant deficient in chloroplast $\omega 6$ desaturase activity. Plant Physiol., 106: 1453-1459.

Franzen, L. G., Rochaix, J. D., Von Heijne, G., 1990. Chloroplast transit peptides from the green alga Chlamydomonas reinhardtii share features with both mitochondrial and higher plant chloroplast presequences. FEBS Lett., 260: 165-168.

Heppard, E. P., Kinney, A. J., Stecca, K. L., Miao, G. H., 1996. Developmental and growth temperature regulation of two different microsomal omega -6 desaturase genes in soybeans. Plant Physiol., 110: 311-319.

Hitz, W. D., Carlson, T. J., Booth, J. R. Jr., Kinney, A. J., Stecca, K. L., Yadav, N. S., 1994. Cloning of a higherplant plastid omega- 6 fatty acid desaturase cDNA and its expression in a cyanobacterium. Plant Physiol., 105: 635-641.

Los, D. E., Murata, N., 1998. Structure and expression of fatty acid desaturase. Biochem. Biophys. Acta., 1394: 3 -15 .

Okuley, J., Lightner, J., Feldmann, K., Yadav, N., Lark, E., Browse, J., 1994. Arabidopsis FAD2 gene encodes the enzyme that is essential for polyunsaturated lipid synthesis. Plant Cell., 6: 147-158.

Miura, Y., Ohta, S., Mano, M., Miyamoto, K., 1986. Isolation and characterization of a unicellular marine green alga exhibiting high activity in dark hydrogen production. Agric. Biol. Chem., 50: 2837-2844.

Miyasaka, H., Kanaboshi, H., Ikeda, K., 2000. Isolation of several anti-stress genes from the halotolerant green alga Chlamydomonas by simple functional expression screening with Escherichia coli. World J. Microbiol. Biotechnol., 16: 23-29.

Miyasaka, H., Ohnishi, Y., Akano, T., Fukatsu, K., Mizoguchi, T., Yagi, K., Maeda, I., Ikuta, Y., Matsumoto, H., Shioji, N., Miura, Y., 1998. Excretion of glycerol by the marine Chlamydomonas sp. strain $\mathrm{W}-80$ in high $\mathrm{CO}_{2}$ cultures. J. Ferment. Bioeng., 85: 123-125.

Murata, N., Wada, H., 1995. Acyl-lipid desaturases and their importance in the tolerance and acclimatization to cold of cyanobacteria. Biochem. J., 308: 1-8.

Rabinowitch, H. D., Rosen, G. M., Fridovich, I., 1987. Contrasting fates of the paraquat monocation radical in Escherichia coli and in Dunaliella salina. Arch. Biochem. Biophys., 257: 352-356.

Sakamoto, T., Bryant, D. A., 1997. Temperature-regulated mRNA accumulation and stabilization for fatty acid desaturase genes in the cyanobacterium Synechococcus sp. strain PCC7002. Mol. Microbiol., 23: 1281-1292.

Sakamoto, T., Wada, H., Nishida, I., Ohmori, M., Murata, N., 1994. Identification of conserved domains in the delta-12 desaturases of cyanobacteria. Plant Mol. Biol., 24: 643-650.

Sato, N., Fujiwara, S., Kawaguchi, A., Tsuzuki, M., 1997. Cloning of a gene for chloroplast $\omega 6$ desaturase of a green alga, Chlamydomonas reinhardtii. J. Biochem., 
122: $1224-1232$.

Schmidt, H., Dresselhaus, T., Buck, F., Heinz, E., 1994. Purification and PCR-based cDNA cloning of a plastidial n-6 desaturase. Plant Mol. Biol., 26: 631-642.

Shanklin, J., Whittle, E., Fox, B. G., 1994. Eight histidine residues are catalytically essential in a membraneassociated iron enzymes, stearyl-CoA desaturase, and are conserved in alkane hydroxylase and xylene monooxygenase. Biochemistry., 33: 12787-12794.

Thompson, J. D., Higgins, D. G., Gibson, T. J., 1994. CLUSTAL W: improving the sensitivity of progressive multiple sequence alignment through sequence weighting, position-specific gap penalties and weight matrix choice. Nucl. Acids. Res., 22: 4673-4680. 